\title{
Founder mutations and genotype-phenotype correlations in Meckel-Gruber syndrome and associated ciliopathies
}

\author{
Katarzyna Szymanska', lan Berry², Clare V Logan', Simon RR Cousins', Helen Lindsay ${ }^{2}$, Hussain Jafri ${ }^{3}, 4$ \\ Yasmin Raashid ${ }^{4}$, Saghira Malik-Shariff, Bruce Castle ${ }^{6}$, Mushtag Ahmed ${ }^{5}$, Chris Bennett ${ }^{5}$, \\ Ruth Carlton ${ }^{2}$ and Colin A Johnson ${ }^{1 *}$
}

\begin{abstract}
Background: Meckel-Gruber syndrome (MKS) is an autosomal recessive lethal condition that is a ciliopathy. MKS has marked phenotypic variability and genetic heterogeneity, with mutations in nine genes identified as causative to date.
\end{abstract}

Methods: Families diagnosed with Meckel-Gruber syndrome were recruited for research studies following informed consent. DNA samples were analyzed by microsatellite genotyping and direct Sanger sequencing.

Results: We now report the genetic analyses of 87 individuals from 49 consanguineous and 19 non-consanguineous families in an unselected cohort with reported MKS, or an associated severe ciliopathy in a kindred. Linkage and/or direct sequencing were prioritized for seven MKS genes (MKS1, TMEM216, TMEM67/MKS3, RPGRIP1L, CC2D2A, CEP290 and TMEM237) selected on the basis of reported frequency of mutations or ease of analysis. We have identified biallelic mutations in 39 individuals, of which 13 mutations are novel and previously unreported. We also confirm general genotype-phenotype correlations.

Conclusions: TMEM67 was the most frequently mutated gene in this cohort, and we confirm two founder splice-site mutations (c.1546 + $1 \mathrm{G}>\mathrm{A}$ and c.870-2A > G) in families of Pakistani ethnic origin. In these families, we have also identified two separate founder mutations for RPGRIP1L (c. 1945 C > T p.R649X) and CC2D2A (c. 3540delA p.R1180SfsX6). Two missense mutations in TMEM67 (c. 755 T > C p.M252T, and c. 1392 C > T p.R441C) are also probable founder mutations. These findings will contribute to improved genetic diagnosis and carrier testing for affected families, and imply the existence of further genetic heterogeneity in this syndrome.

Keywords: Meckel-Gruber syndrome, Genotype-phenotype, Founder mutation

\section{Background}

MKS is an autosomal recessive lethal condition characterized by occipital meningoencephalocele, polycystic kidneys, postaxial polydactyly and ductal plate malformation of the liver. Other frequently observed features can include the Dandy-Walker malformation (or other posterior fossa defects), dextrocardia, bowing of long bones, cleft lip and/or palate, situs inversus, low set ears, microphthalmia and iris coloboma. To date, mutations in nine MKS genes

\footnotetext{
* Correspondence: c.johnson@leeds.ac.uk

${ }^{1}$ Section of Ophthalmology and Neurosciences, Leeds Institute of Molecular Medicine, St. James's University Hospital, Leeds, UK

Full list of author information is available at the end of the article
}

are reported as causative (Table 1 ). The protein products of the nine MKS genes are all involved in the structure or function of either the ciliary basal body/transition zone or the axoneme of the primary cilia [1-5]. MKS is, therefore, the most severe inherited condition in a suite of similar conditions known as ciliopathies. Other conditions with ciliary involvement include Joubert syndrome, nephronophthisis, Bardet-Biedl syndrome, $\mathrm{COACH}$ syndrome and Senior-Løken syndrome. All of these syndromes are allelic at some loci, and share some phenotypic features. Primary cilia are ubiquitous organelles, which contribute to the multiorgan involvement in MKS and other ciliopathy phenotypes.

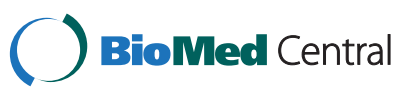

(c) 2012 Szymanska et al.; licensee BioMed Central Ltd. This is an Open Access article distributed under the terms of the Creative Commons Attribution License (http://creativecommons.org/licenses/by/2.0), which permits unrestricted use, distribution, and reproduction in any medium, provided the original work is properly cited. 
Table 1 Genes mutated in Meckel-Gruber syndrome and related ciliopathies

\begin{tabular}{|c|c|c|c|c|c|c|c|}
\hline Locus & $\begin{array}{l}\text { Chromosome } \\
\text { location }\end{array}$ & $\begin{array}{l}\text { Gene } \\
\text { name }\end{array}$ & $\begin{array}{l}\text { Protein } \\
\text { name }\end{array}$ & Other ciliopathies & $\begin{array}{l}\text { Key } \\
\text { reference }\end{array}$ & $\begin{array}{l}\text { Common mutation } \\
\text { in population }\end{array}$ & Reference \\
\hline MKS1 & $17 q 22$ & MKS1 & MKS1 & $\mathrm{BBS13}$ & [1] & Finnish - c. 1408-35_1408-7del29 & [1] \\
\hline \multirow[t]{2}{*}{ MKS2 } & $11 q 13.1$ & TMEM216 & TMEM216 & JBTS2 & [2] & Ashkenazi - p.R73L & [2] \\
\hline & $11 q 12.2$ & TMEM138 & TMEM138 & JBTS16 & [3] & & \\
\hline MKS3 & $8 q 22.1$ & TMEM67 & MECKELIN & JBTS6, NPHP11 & [4] & Pakistani - c. $1575+1 \mathrm{G}>\mathrm{A}$ & [4] \\
\hline MKS4 & $12 q 21.32$ & CEP290 & CEP290 & BBS14, JBTS5, LCA10, NPHP6, SLSN6 & [5] & & \\
\hline MKS5 & $16 q 12.2$ & RPGRIPIL & RPGRIP1L & JBTS7, NPHP8 & [6] & Mixed European -p.T615P & [11] \\
\hline MKS6 & $4 p 15.33$ & $C C 2 D 2 A$ & CC2D2A & JBTS9 & [7] & Finnish - c. 1762 C>T & [7] \\
\hline MKS7 & $3 q 22.1$ & NPHP3 & NPHP3 & NPHP3 & {$[8]$} & & \\
\hline MKS8 & $12 q 24.31$ & TCTN2 & TCTN2 & & [9] & & \\
\hline MKS9 & 17p11.2 & B9D1 & B9D1 & & [10] & & \\
\hline
\end{tabular}

The nine genes reported to be mutated are listed, with key references indicated. Common founder mutations that have been identified previously are also indicated, with the ethnicity of the population studied and any relevant reference.

The genetic heterogeneity and phenotypic variability in MKS have hindered the development of an evidencebased strategy for genetic diagnosis. To facilitate the process of genetic diagnosis for families, the unequivocal identification of pathogenic variants, genotype-phenotype correlations and founder mutations in specific ethnic groups, therefore, has important clinical utility. To further define the allelic series of pathogenic mutations for seven of the nine known MKS genes, we have screened an unselected cohort of 87 separate individuals affected with MKS, from a total of 49 consanguineous families and 19 non-consanguineous. We report the identification of mutations in 26 consanguineous and 13 non-consanguineous families, and describe a total of 18 previously unreported mutations.

\section{Methods}

Patient ascertainment and research ethics statement

Blood samples and/or DNA samples from fetuses diagnosed with Meckel-Gruber or Meckel-like syndrome, unaffected siblings and parents were collected from UK centers. Adults were recruited to research studies after informed consent, with adherence to the Declaration of Helsinki ethical principles for medical research involving human subjects. Studies had favorable ethical approval from Leeds (East) Local Research Ethics Committee (study title "Molecular genetic investigations of autosomal recessive conditions", REC reference number 08/H1306/85). DNA was extracted using QIAGEN (Crawley, West Sussex, UK) extraction kits following the manufacturer's protocol by the Yorkshire Regional Genetics Service (http://www.leedsth. nhs.uk/sites/genetics/). Other DNA samples were obtained from referring clinicians or collaborators.

\section{Microsatellite genotyping and direct Sanger sequencing} DNA from affected individuals was genotyped for microsatellite markers that flanked seven of the nine known MKS genes (MKS1, TMEM216, TMEM67/MKS3, RPGRIP1L,
CC2D2A, CEP290 and TMEM237) at $<1 \mathrm{cM}$ genetic distance (Additional file 1: Table S1). Markers were PCR amplified using standard protocols, with the forward primer 5/ end-labelled with FAM (Sigma-Aldrich Ltd., Gillingham, Dorset, UK). Samples were run on an ABI3100 sequencer with ROX-500 (Applied Biosystems, Inc. Carlsbad, CA, USA) size standard. In samples from singleton or multiplex affected individuals of consanguineous origin, two homozygous markers indicated putative linkage to a locus under investigation, prioritizing the gene for subsequent sequencing. In non-consanguineous multiplex families, two or more affected individuals sharing haplotypes for flanking markers indicated putative linkage to a locus. DNA samples from singleton non-consanguineous samples were screened for the seven MKS genes described above. If linkage analysis (when performed) did not specifically exclude the involvement of the MKS1, MKS2, MKS3 and MKS6 loci, patients were then sequenced for the MKS1, TMEM216, TMEM67 and $C C 2 D 2 A$ genes. PCR primers were designed using Primer3 software (http://frodo.wi.mit.edu/primer3/) covering all coding exons and flanking intronic regions (Additional file 2: Table S2). A total of 188 coding exons were amplified by standard PCR protocols. PCR products were then purified using Exo-SAP (USB) following the manufacturer's protocol. Bidirectional Sanger sequencing was performed using a "BigDyev3.0" sequencing kit (Applied Biosystems, Inc.) by standard protocols recommended by the manufacturer. Samples were run on a ABI3100 sequencer and analyzed using "SeqScape" and "Sequencing Analysis" software (both Applied Biosystems, Inc.).

\section{Analysis of mutations}

The expected segregation of putative mutations was confirmed in families, whenever possible, and their absence was confirmed in databases of common benign variants (dbSNP http://www.ncbi.nlm.nih.gov/projects/SNP/, 1000 Genomes Project http://www.1000genomes.org/ and http:// 
Table 2 Clinical data and sequencing results of consanguineous and non-consanguineous patients with MKS and MKS-like phenotypes

\begin{tabular}{|c|c|c|c|c|c|c|c|c|c|c|c|}
\hline \multicolumn{2}{|c|}{ Sample } & \multicolumn{3}{|c|}{ Mutation } & \multicolumn{7}{|c|}{ Phenotype } \\
\hline Id & Ethnicity & Gene & Allele 1 & Allele 2 & $\mathrm{OE}$ & PK & PD & DPM & CLP & DWM & Other \\
\hline \multicolumn{12}{|c|}{ Consanguineous } \\
\hline $\begin{array}{l}102+103+ \\
244+270\end{array}$ & Pakistani & MKS1 & $\begin{array}{l}\text { c. } 1448 \text { _ } \\
\text { 1451dupCAGG }\end{array}$ & $\begin{array}{l}\text { MKS1 c. } 1448 \\
\text { 1451dupCAGG }\end{array}$ & + & + & + & & + & & $\begin{array}{l}\text { Short neck, low set } \\
\text { ears, bilateral talipes, } \\
\text { syndactyly, micropenis, } \\
\text { situs inversus, congenital } \\
\text { heart defect inc. } \\
\text { dextrocardia, short femurs } \\
\text { and short spindle-shaped } \\
\text { tibiae, deformed tongue }\end{array}$ \\
\hline 264 & Jordanian & MKS1 & $\begin{array}{l}\text { c. } 1408-35 \text { 1408- } \\
6 \text { del30N }\end{array}$ & $\begin{array}{l}\text { c.1408-35_1408- } \\
6 \text { del30 }\end{array}$ & & & & & & & diagnosed with MKS \\
\hline $42+43$ & Pakistani & TMEM138 & $\begin{array}{l}\text { c. A287G } \\
\text { p.H96R }\end{array}$ & $\begin{array}{l}\text { c. A287G } \\
\text { p.H96R }\end{array}$ & + & + & & + & & & \\
\hline $29 A+33 A$ & $\begin{array}{l}\text { Pakistani/ } \\
\text { Mirpuri }\end{array}$ & TMEM67 & c. $1575+1 \mathrm{G}>\mathrm{A}$ & c. $1575+1 \mathrm{G}>\mathrm{A}$ & + & + & + & + & & & \\
\hline 70 & $\begin{array}{l}\text { Pakistani/ } \\
\text { Mirpuri }\end{array}$ & TMEM67 & c. $1575+1 \mathrm{G}>\mathrm{A}$ & c. $1575+1 \mathrm{G}>\mathrm{A}$ & & + & & & & + & \\
\hline 76 & $\begin{array}{l}\text { Pakistani/ } \\
\text { Mirpuri }\end{array}$ & TMEM67 & c. $1575+1 \mathrm{G}>\mathrm{A}$ & c. $1575+1 \mathrm{G}>\mathrm{A}$ & + & + & & & & & \\
\hline 77117 & Pakistani & TMEM67 & c. $1575+1 \mathrm{G}>\mathrm{A}$ & c. $1575+1 \mathrm{G}>\mathrm{A}$ & & & & & & & diagnosed with MKS \\
\hline 51 & $\begin{array}{l}\text { Pakistani/ } \\
\text { Mirpuri }\end{array}$ & TMEM67 & c. $870-2 A>G$ & c. $870-2 A>G$ & + & & & & & & \\
\hline 73 & $\begin{array}{l}\text { Pakistani/ } \\
\text { Mirpuri }\end{array}$ & TMEM67 & c. $870-2 A>G$ & c. $870-2 A>G$ & + & + & & + & & & \\
\hline 319 & British & TMEM67 & $\begin{array}{l}\text { c. } 1392 \text { C > T } \\
\text { p.R441C }\end{array}$ & $\begin{array}{l}\text { c. } 1392 \text { C > T } \\
\text { p.R441C }\end{array}$ & & + & & + & & & $\begin{array}{l}\text { some dialation of } \\
\text { pancreatic ducts, } \\
\text { hydrocephalus, } \\
\text { posterior fossa cyst }\end{array}$ \\
\hline 347 & Pakistani & TMEM67 & $\begin{array}{l}\text { c. } 1392 \text { C > T } \\
\text { p.R441C }\end{array}$ & $\begin{array}{l}\text { c. } 1392 \text { C > T } \\
\text { p.R441C }\end{array}$ & & & & & & & diagnosed with MKS \\
\hline $67 F B$ & Pakistani & TMEM67 & $\begin{array}{l}\text { c. } 647 \mathrm{del} \text {, } \\
\text { p.E216fsX221 }\end{array}$ & $\begin{array}{l}\text { c. } 647 \mathrm{delA}, \\
\text { p.E216fsX221 }\end{array}$ & + & + & & + & + & & \\
\hline P95 & Pakistani & TMEM67 & $\begin{array}{l}\text { c. } 1127 \mathrm{~A}>\mathrm{C} \\
\text { p.Q376P }\end{array}$ & $\begin{array}{l}\text { c. } 1127 \mathrm{~A}>\mathrm{C} \\
\text { p.Q376P }\end{array}$ & + & + & & + & & & \\
\hline 125 & Omani & TMEM67 & $\begin{array}{l}\text { c. } 383 \text { 384delAC } \\
\text { p.H128fsX140 }\end{array}$ & $\begin{array}{l}\text { c. 383_384delAC } \\
\text { p.H128fsX140 }\end{array}$ & + & + & + & & & + & \\
\hline 170 & Turkish & TMEM67 & c. $1674+1 G>A^{N}$ & c. $1674+1 G>A^{N}$ & & & & & & & diagnosed with MKS \\
\hline 205 & Chinese & TMEM67 & $\begin{array}{l}\text { c. } 1615 \text { C > T } \\
\text { p.R549C }\end{array}$ & $\begin{array}{l}\text { c. } 1615 \text { C > T } \\
\text { p.R549C }\end{array}$ & & + & & + & & & $\begin{array}{l}\text { hypoplastic } \\
\text { cerebellum, small } \\
\text { fourth ventricle with } \\
\text { large cisterna magna, } \\
\text { small defect in superior } \\
\text { aspect of occipital bone }\end{array}$ \\
\hline C28 & Pakistani & TMEM67 & $\begin{array}{l}\text { c. } 274 \mathrm{G}>\mathrm{A} \\
\text { p.G92R }\end{array}$ & $\begin{array}{l}\text { c. } 274 \mathrm{G}>\mathrm{A} \\
\text { p.G92R }\end{array}$ & & & & & & & $\begin{array}{l}\text { MTS, coloboma, } \\
\text { mental retardation }\end{array}$ \\
\hline 39 & $\begin{array}{l}\text { Pakistani/ } \\
\text { Mirpuri }\end{array}$ & CEP290 & $\begin{array}{l}\text { c. } 1429 C>T \\
\text { p.R477X }\end{array}$ & $\begin{array}{l}\text { c. } 1429 C>T \\
\text { p.R477X }\end{array}$ & & + & & + & & & \\
\hline 292 & Pakistani & CEP290 & $\begin{array}{l}\text { c. 954delT } \\
\text { p.S318fs 16 } X^{N}\end{array}$ & $\begin{array}{l}\text { c. 954delT } \\
\text { p.S318fs16XN }\end{array}$ & + & & & & & & \\
\hline 333 & Pakistani & CEP290 & $\begin{array}{l}\text { c. } 5744 \text { insT } \\
\text { p.G1915Ffs X1 }\end{array}$ & $\begin{array}{l}\text { c. } 5744 \text { insT } \\
\text { p.G1915Ffs } \times 1^{N}\end{array}$ & + & & & & & & \\
\hline 207 & Pakistani & RPGRIPIL & $\begin{array}{l}\text { c. } 1945 C>T \\
\text { p. } R 649 X^{N}\end{array}$ & $\begin{array}{l}\text { c. } 1945 \text { C > T } \\
\text { p. } R 649 X^{N}\end{array}$ & + & + & + & & & & small cerebellum \\
\hline
\end{tabular}


Table 2 Clinical data and sequencing results of consanguineous and non-consanguineous patients with MKS and MKS-like phenotypes (Continued)

\begin{tabular}{|c|c|c|c|c|c|c|c|c|c|c|c|}
\hline 336 & Pakistani & RPGRIP1L & $\begin{array}{l}\text { c. } 1945 \text { C > T } \\
\text { p.R649X }\end{array}$ & $\begin{array}{l}\text { c. } 1945 C>T \\
\text { p.R649X }\end{array}$ & & & & & & & diagnosed with MKS \\
\hline 158 & Pakistani & CC2D2A & $\begin{array}{l}\text { c. } 3540 \text { delA } \\
\text { p.R1180SfsX6 }\end{array}$ & $\begin{array}{l}\text { c. } 3540 \text { delA } \\
\text { p.R1180SfsX6 }\end{array}$ & + & + & + & + & + & & $\begin{array}{l}\text { low set ears, pulmonary } \\
\text { hypoplasia, intestinal } \\
\text { malrotation, markedly } \\
\text { enlarged pancreas- irregular } \\
\text { ducts on histology, brain } \\
\text { shows dilated fourth } \\
\text { ventricle with small } \\
\text { cerebellum, poorly } \\
\text { developed pyramidal } \\
\text { tracts and some possible } \\
\text { dysplasia in the basal } \\
\text { ganglia }\end{array}$ \\
\hline 180 & Pakistani & CC2D2A & $\begin{array}{l}\text { c. } 3540 \text { delA } \\
\text { p.R1180SfsX6 }\end{array}$ & $\begin{array}{l}\text { c. } 3540 \text { delA } \\
\text { p.R1180Sfs X6 }\end{array}$ & + & + & + & & & + & \\
\hline 261 & Jordanian & TMEM237 & $\begin{array}{l}\text { c. } 1066 \_1067 \mathrm{dupC} \\
\text { p.Q356PfsX23 }\end{array}$ & $\begin{array}{l}\text { c. } 1066 \_1067 \text { dupC } \\
\text { p.Q356PfsX23 }\end{array}$ & & & & & & & $\begin{array}{l}\text { meningomyelocele, } \\
\text { developmental delay, } \\
\text { cortical visual impairment }\end{array}$ \\
\hline 178 & $\begin{array}{l}\text { Pakistani/ } \\
\text { Mirpuri }\end{array}$ & TMEM67 & $\begin{array}{l}\text { c. } 1615 C>T \\
\text { p.R549C }\end{array}$ & not detected & & & & & & & diagnosed with MKS \\
\hline $16+17$ & Pakistani & CC2D2A & $\begin{array}{l}\text { c. } 685 \text { 687delGAA } \\
\text { het p.E229del }\end{array}$ & not detected & & + & & + & & & \\
\hline $66 \mathrm{~F} 1+66 \mathrm{~F} 2$ & Pakistani & CC2D2A & $\begin{array}{l}\text { c. } 685 \text { 687delGAA } \\
\text { het p.E229del }\end{array}$ & not detected & + & + & + & + & & & $\begin{array}{l}\text { absent uterus, } \\
\text { micrognathia, } \\
\text { bilateral talipes, } \\
\text { low set ears, wide } \\
\text { spread eyes }\end{array}$ \\
\hline \multicolumn{12}{|c|}{ Non-Consanguineous } \\
\hline 106 & British & MKS1 & $\begin{array}{l}\text { c. } 1408-35 \text { 1408- } \\
\text { 7del29 }\end{array}$ & $\begin{array}{l}\text { c. } 1408-35 \text { 1408- } \\
\text { 7del29 }\end{array}$ & + & + & + & + & & & \\
\hline 77172 & Finnish & MKS1 & $\begin{array}{l}\text { c. } 1408-35 \_1408- \\
7 \text { del29 }\end{array}$ & $\begin{array}{l}\text { c. } 811 \mathrm{delC} \\
\text { p.H271fs } \times 29^{N}\end{array}$ & & & & & & & diagnosed with MKS \\
\hline 74699 & British & MKS1 & $\begin{array}{l}\text { c. } 1408-35 \text { 1408- } \\
\text { 7del29 }\end{array}$ & $\begin{array}{l}\text { c. } 1408-35 \text { 1408- } \\
\text { 7del29 }\end{array}$ & & & & & & & diagnosed with MKS \\
\hline $162+163$ & British & TMEM216 & $\begin{array}{l}\text { c. } 253 C>T \\
\text { p. } R 85 X^{+}\end{array}$ & $\begin{array}{l}\text { c. } 253 \mathrm{C}>\mathrm{T} \\
\text { p. } R 85 \mathrm{X}^{+}\end{array}$ & + & + & + & + & + & & $\begin{array}{l}\text { facial dysmorphism, } \\
\text { postural deformities } \\
\text { of limbs, small } \\
\text { perimembranous } \\
\text { ventricular septal defect, } \\
\text { intestinal malrotation }\end{array}$ \\
\hline $176+177$ & British & TMEM67 & $\begin{array}{l}\text { c. } 1426 \mathrm{C}>\mathrm{T} \\
\text { p.P476S }\end{array}$ & c. $2440-3$ C > A & + & + & + & + & & & $\begin{array}{l}\text { flexion deformity of } \\
\text { elbows and wrists, } \\
\text { low set ears }\end{array}$ \\
\hline 186 & British & TMEM67 & $\begin{array}{l}\text { c. } 755 \mathrm{~T}>\mathrm{C} \\
\text { p.M252T }\end{array}$ & $\begin{array}{l}\text { c. } 653 \mathrm{G}>\mathrm{T} \\
\text { p.R208X+†† }\end{array}$ & + & + & & & & & \\
\hline 302 & British & TMEM67 & $\begin{array}{l}\text { C.755 T >C } \\
\text { p.M252T }\end{array}$ & $\begin{array}{l}\text { c. } 651+5 \mathrm{G}>\mathrm{A} \\
\text { p.V217Vfs }\end{array}$ & & + & & + & & + & $\begin{array}{l}\text { agenesis of corpus } \\
\text { callosum }\end{array}$ \\
\hline 83527 & $\begin{array}{l}\text { Norwegian- } \\
\text { Indian }\end{array}$ & TMEM67 & $\begin{array}{l}\text { c. } 755 \mathrm{~T}>\mathrm{C} \\
\text { p.M252T }\end{array}$ & $\begin{array}{l}\text { c. } 2882 C>A \\
\text { p.S961YN }\end{array}$ & + & + & & + & & & \\
\hline $74406 a+b$ & & TMEM67 & $\begin{array}{l}\text { c. } 1351 \mathrm{C}>\mathrm{T} \\
\text { p.R451X }\end{array}$ & $\begin{array}{l}\text { c. } 2108 \mathrm{~T}>\mathrm{A} \\
\text { p.V673A }\end{array}$ & & + & & + & & & $\begin{array}{l}\text { mental retardation, } \\
\text { retinal coloboma }\end{array}$ \\
\hline $210+239$ & Dutch & CEP290 & $\begin{array}{l}\text { c. } 679 \_680 \text { delGA } \\
\text { p.E227SfsX2 }\end{array}$ & $\begin{array}{l}\text { c. } 1984 C>T \\
\text { p.Q662X }\end{array}$ & & + & & + & & + & $\begin{array}{l}\text { abnormal cerebellum, } \\
\text { wide nasal bridge, } \\
\text { extended abdomen, } \\
\text { thoracic and } \\
\text { abdominal situs inversus, } \\
\text { intestinal rotation, small } \\
\text { bladder, uterus duplex }\end{array}$ \\
\hline
\end{tabular}




\begin{tabular}{|c|c|c|c|c|c|c|c|c|c|}
\hline $153+154$ & French & CEP290 & $\begin{array}{l}\text { c. } 2251 C>T \\
\text { p.R751X }\end{array}$ & $\begin{array}{l}\text { c. } 4864 \text { insTdelCG } \\
\text { p.R1622Ffs X9 }\end{array}$ & & + & & & \\
\hline 166 & British & RPGRIPIL & $\begin{array}{l}\text { c. } 1829 \mathrm{~A}>C \\
\text { p.H610P }\end{array}$ & $\begin{array}{l}\text { c. } 721 \text { 724delAATG } \\
\text { p.N241fs X25 }\end{array}$ & + & + & + & + & \\
\hline 128 & British & $C C 2 D 2 A$ & $\begin{array}{l}\text { c. } 3544 \mathrm{~T}>\mathrm{C} \\
\text { p.W1182R }\end{array}$ & $\begin{array}{l}\text { c. 3774_37744insT } \\
\text { p.E1259fsX1 }\end{array}$ & & & & & diagnosed with MKS \\
\hline $36+36 A$ & $\begin{array}{l}\text { Pakistani/ } \\
\text { Gujarati }\end{array}$ & RPGRIPIL & $\begin{array}{l}\text { c. } 466 C>T \\
\text { p.R156C*N }\end{array}$ & not detected & + & + & & & \\
\hline $111+112$ & Portuguese & CEP290 & $\begin{array}{l}\text { c. } 1451 \mathrm{del} A \\
\text { p.K484fsX8 }\end{array}$ & not detected & + & + & + & & \\
\hline 202 & British & CC2D2A & $\begin{array}{l}\text { c. } 685 \text { 687delGAA } \\
\text { p.E229del** }\end{array}$ & not detected & + & + & & & $\begin{array}{l}\text { craniofacial } \\
\text { abnormalities related } \\
\text { to oligohydramnios, } \\
\text { bone-cartilage junctions } \\
\text { showed disarray }\end{array}$ \\
\hline
\end{tabular}

CLP, cleft lip/palate; DPM, ductal plate malformation; DWM, Dandy-Walker malformation; OE, occipital encephalocele; PD, polydactyly; PK, polycystic kidneys; * in cis with c. $3790 \mathrm{G}>\mathrm{A}$ het p.D1264N, ${ }^{* *}$ in cis with c. $3893 \mathrm{~T}>\mathrm{A}$ p.V1298D; ${ }^{\dagger}$ p.R85X allele was present in 2/10,266 European/African/American controls in the Exome Variant Server (EVS) database, ${ }^{+\dagger}$ p.P476S allele present in 6/7,012 European/American controls (EVS), ${ }^{++}$p.R208X allele present in 8/7,012 European/ American controls (EVS). The remaining changes are excluded in about 10,000 European/African/American controls (EVS). ${ }^{N}$ indicates a novel mutation that has not previously been reported. ${ }^{a}$ indicates that affected siblings $153+154$ are compound heterozygotes for CEP290 mutations, but both also carry a third heterozygous putative pathogenic mutation in TMEM216 c. $188 \mathrm{~T}>\mathrm{G}$ p.L63R.

evs.gs.washington.edu/EVS/ as appropriate). The pathogenic potential of putative missense mutations was assessed by analysis with PolyPhen2 (http://genetics.bwh.harvard. edu/pph2/), or by manual comparison of CLUSTALX alignments of protein homologues to determine the phylogenetic conservation of mutated amino acid residues. We confirmed the absence of the mutant alleles in a panel of 96 DNA samples from ethnically-matched normal control individuals.

\section{Results}

In this study we identified mutations in $\mathrm{n}=38 / 68$ (55.9\%) families that were recruited to the study (Table 2). Out of all families with identified mutations, 19 (50\%) had changes in TMEM67 (Figure 1a), which highlights the prevalence of TMEM67 mutations as a major cause of MKS. The second most commonly mutated genes were CEP290 and MKS1 (each $\mathrm{n}=5 / 68$ families; 3.2\%). Mutations in CC2D2A and RPGRIP1L each had mutations in $\mathrm{n}=3 / 68$ families (7.9\%). TMEM216, TMEM138 and TMEM237 each had mutations in only one family ( $2.6 \%$ each), confirming that these were uncommon causes of the MKS phenotype.

In addition, six families were identified with a single heterozygous mutation in an MKS gene, but we were unable to identify a second pathogenic variant. CC2D2A p. E229del is probably a common variant, and it was detected as a single heterozygous variant in two families of Pakistani origin. In family $36+36 \mathrm{~A}$ and family 202 , two changes in the same gene were detected but were inherited in cis from the paternal line, so the pathogenic potential of these variants is unclear. We did not detect any other potential pathogenic changes in any of the seven MKS genes that we screened for these patients. Family 178 has the single heterozygous missense mutation $\mathrm{p}$.
R549C that is likely to be pathogenic because the same mutation is found in the homozygous state in family 205. This mutation may be a Chinese founder mutation (K. Szymanska, personal communication).

We identified homozygous mutations predicted to be pathogenic in $50 \%$ of consanguineous families (Figure 1b). Two families had mutations in MKS1. Family 264 had the homozygous MKS1 mutation c. 1408-35_1408-6del30 (Figure 1c), which is almost identical to the "Finn major" Finnish founder mutation (c. 1408-35_1408-7del29) with one base-pair difference. Since family 264 is of Jordanian origin and, therefore, has a different genetic background from northern European patients with the "Finn major" mutation, this finding suggests a mutation hot spot in this intronic region of the $M K S 1$ gene. We identified three different homozygous mutations in CEP290 in Pakistani families. Two of these were frameshift mutations with one nonsense, predicted to cause nonsense-mediated decay.

The majority of identified mutations were found in TMEM67 (Figure 1b), comprising $\mathrm{n}=14 / 47$ (29.8\%) families. Two splice-site mutations and one missense mutation were identified as recurrent in families and, therefore, probable founder mutations (Figure 1d). In patients of Pakistani ethnic origin, the two TMEM67 splice-site mutations are c. $1546+1 \mathrm{G}>\mathrm{A}$ and c. $870-2 \mathrm{~A}>\mathrm{G}$, previously reported as common mutations in TMEM67 [6]. We identified the homozygous missense mutation $\mathrm{p}$. R441C in two families (319 and 347), a mutation reported previously in the heterozygous state for patients with $\mathrm{COACH}$ syndrome [7]. A missense mutation affecting the same amino-acid residue, p.R441L, has also been reported previously in an MKS patient [8]. Since families 319 and 347 have different ethnic origins (British and Pakistani, 
(a) Genes mutated in MKS and MKS-like
phenotype

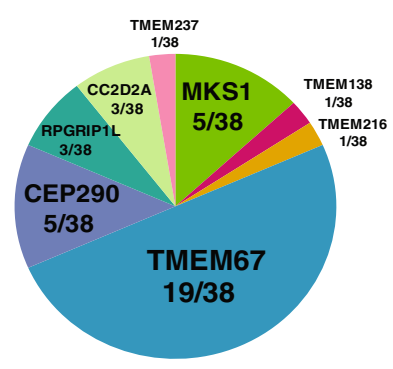

(c)

Mutations in MKS1

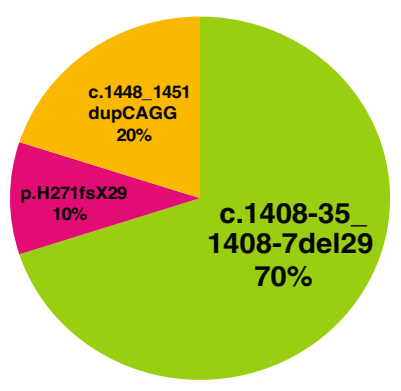

(e)

Incidence of MKS mutations in (b) Incidence of MKS mutations in consanguineous patients

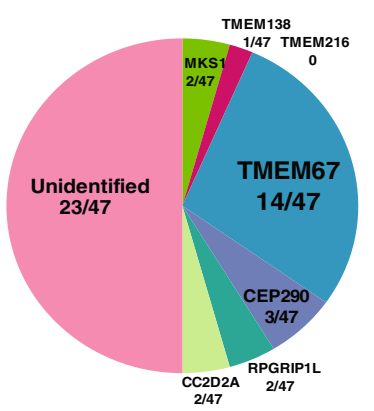

(d)

Mutations in TMEM67

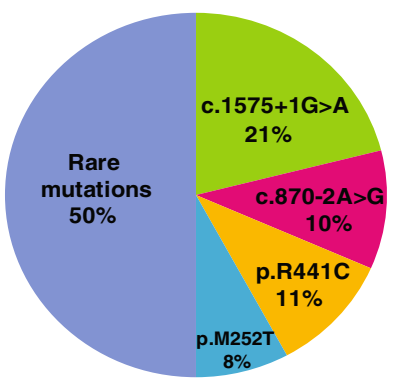
nonconsanguineous patients

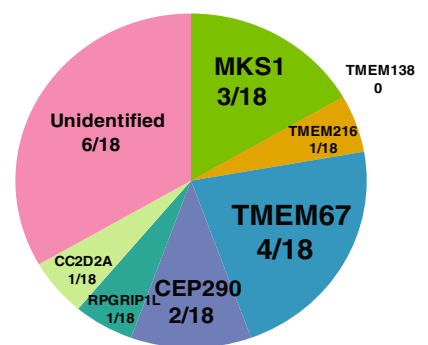

Figure 1 Pie charts summarizing mutation analysis in MKS and MKS-like patients. a) frequency of genes mutated in MKS and MKS-like phenotype; b) frequency of MKS genes mutations in consanguineous patients; c) common mutations in MKS1; d) common mutations in TMEM67; e) frequency of MKS genes mutations in non-consanguineous patients.

respectively), this emphasizes the mutability of arginine residues and their importance to the function of the protein since the neighboring residue p.R440 is also mutated in MKS and MKS-associated ciliopathies [9-11].

We identified probable founder mutations in both RPGRIP1L and CC2D2A for families of Pakistani ethnic origin. The RPGRIP1L nonsense mutation c. $1945 \mathrm{C}>\mathrm{T}$ p. R649X was observed in families 207 and 336, which are reported to be unrelated. The frameshift mutation in CC2D2A c. 3540delA p.R1180SfsX6 occurred in the unrelated families 158 and 180, with polydactyly noted as an obligatory feature in all affected individuals.
Two-thirds $(n=13 / 19)$ of non-consanguineous families had their causative mutations identified (Figure 1e), with the majority of mutations $(n=10 / 13)$ in the compound heterozygous state. The majority of identified mutations were found in the TMEM67 gene, with mutations in MKS1 and CEP290 the next frequent. In our cohort, the "Finn major" mutation was found in all MKS1-mutated patients, either in the homozygous state for two patients (families 106 and 74,699 of British origin), and in one patient (family 77,172 of Finnish origin) as a compound heterozygous mutation in trans with the frameshift mutation p.H271fsX29. Overall, the MKS1 "Finn major" mutation 
was the most frequent (Figure 1c). The heterozygous missense mutation p.M252T accounted for 30\% of identified alleles in TMEM67 in non-consanguineous patients. The previously reported common Finnish $C C 2 D 2 A$ mutation is absent in our cohort [12], even though the MKS1 "Finn major" Finnish mutation seems frequent. This suggests that the latter is more widespread throughout European populations, whereas the $C C 2 D 2 A$ mutation seems to be less common outside Scandinavia.

\section{Discussion}

There are previous reports of genotype-phenotype correlations in MKS $[8,9,13]$. We confirm some of these correlations with the available clinical data for our cohort of MKS patients. Occipital encephalocele and polycystic kidneys were almost obligatory features for all patients. Individuals with TMEM67 mutations frequently had a diagnosis of ductal plate malformation in the liver $(n=10$ / $19)$, but polydactyly was infrequent $(n=3 / 19)$ compared to RPGRIP1L and CC2D2A mutated individuals $(\mathrm{n}=4 / 6$; $P<0.001$, chi-squared test) The Dandy-Walker malformation (or a posterior fossa defect) was occasionally observed in patients with TMEM67 mutations $(\mathrm{n}=3 / 19)$. Retinal colobomata were only observed for TMEM67-mutated individuals $(n=2 / 19)$. Furthermore, situs or gut malrotation defects were never caused by TMEM67 mutations $(n=0 / 19)$, in contrast to the occasional manifestation of these clinical features with MKS1, TMEM216, CEP290 or RPGRIP1L mutations ( $\mathrm{n}=4 / 17 ; P<0.05$, chi-squared test).

Mutation analysis in our MKS and MKS-associated ciliopathy cohort has allowed us to observe some common mutations that have arisen from probable founder effects, supported by the observation of common shared haplotypes in affected individuals (Additional file 3: Figure S1). These observations will allow initial prioritization of gene and exon screened in affected patients. Patients diagnosed with MKS, and that have additional features of ductal plate malformation and/or retinal coloboma, should be tested for TMEM67 mutations since, in any case, MKS mutations are most frequent in this gene. In consanguineous families of Pakistani origin, the TMEM67 splice-site mutations c. $1546+1 \mathrm{G}>\mathrm{A}$ and c. $870-2 \mathrm{~A}>\mathrm{G}$ should be prioritized. In addition, screening for missense mutations between amino acid residues 250 to 570 would detect a third $(\mathrm{n}=10 / 29)$ of all of the TMEM67 mutations in this cohort. It is likely that missense or nonsense mutations of conserved arginine residues in this region (for example, R441C, R451X and R549C), may be recurrent and could, therefore, be founder mutations in other population groups. In consanguineous Pakistani families, the probable founder mutations RPGRIP1L c. $1945 \mathrm{C}>\mathrm{T}$ p.R649X and CC2D2A c. 3540delA p.R1180SfsX6 should also be prioritized. For families of northern European (including British) origin, without a known history of consanguinity, testing the TMEM67 missense mutation p.M252T may be useful, but the most common mutation is the MKS1 "Finn major" mutation. Our results demonstrate the broad phenotypic variability in MKS and the lack of clear genotype-phenotype correlations to guide diagnostic choices. Furthermore, some MKS mutations, such as the TMEM67 p.R440Q missense mutation, are allelic for Joubert syndrome and other ciliopathies.

The molecular basis of the phenotypic variability in MKS may arise from oligogenic inheritance [14], where a third modifier allele modifies the phenotypic effect of two recessive alleles. It is interesting to note that many ciliopathy and ciliary-related proteins interact and are reported to create functional modules that are localized to discrete structural regions of the cilium, such as the transition zone [1-3,5]. The effect of modifier alleles may be to abrogate interactions between components of a functional module, which may disrupt protein complexes or signaling pathways giving rise to the ciliopathy phenotype. We identified four different heterozygous changes in six patients, in the absence of a second detectable pathogenic mutation in the same gene or any other mutations in other MKS genes. These heterozygous alleles could be potential modifier alleles, but we have not exhaustively excluded the possibility that a second pathogenic mutation is a large deletion spanning exons and/or introns in the same MKS gene, which would not be detected with PCR amplification and direct sequencing alone. Although we have not assessed gene dosage in these genes by, for example, a multiplex ligation-dependent probe amplification strategy, we have seen no evidence of allele drop-out at the same or other known MKS loci following genome-wide SNP genotyping of consanguineous patients (individuals $178,16+17$ and 66 F1 + 66 F2). We have also not excluded the possibility that a second point mutation occurs deep within introns or regulatory elements of the same MKS gene. Interestingly, two affected siblings $(153+154)$ were compound heterozygotes for CEP290 mutations (Table 2), but also carried a third heterozygous putative mutation c. $188 \mathrm{~T}>$ G p.L63R in TMEM216. This was the only occurrence of possible triallelic inheritance in our cohort for the seven MKS genes that we screened, although the pathogenic potential of this third TMEM216 allele remains unclear.

\section{Conclusion}

In conclusion, our data provide further useful information about the mutational load in MKS patients from different ethnic backgrounds. With the ever-increasing power and affordability of genetic sequencing technologies, there is now the clear opportunity for the further rapid and robust identification of mutations in patients referred for a defined condition. As a prerequisite, there remains a pressing clinical need for the dissemination of mutations identified on a research basis, and the establishment of 
databases that provide detailed clinical phenotypes and allelic series for specific genes.

\section{Additional files}

Additional file 1: Table S1. Primer sequences of microsatellite markers used for genotyping of MKS loci.

Additional file 2: Table S2. Primer sequences used for direct Sanger sequencing of MKS genes.

Additional file 3: Figure S1. Haplotypes for common mutations in TMEM67, CC2D2A and RPGRIP1L. Putative shared common disease haplotypes (genotypes in bold) are shown for the indicated microsatellite markers on the left that flank the MKS genes TMEM67, CC2D2A and RPGRIP1L. The numerical identifier of each affected individual is shown underneath each haplotype (see Table 2 for further details).

\section{Abbreviations}

BBS: Bardet-Biedl syndrome; JBTS: Joubert syndrome; LCA: Leber congenital amaurousis; MKS: Meckel-Gruber syndrome; NPHP: Nephronophthisis; SLSN: Senior-Løken syndrome.

\section{Competing interests}

The authors declare that they have no competing interests.

\section{Authors' contributions}

$H J, Y R, S M-S, B C, C B$ and $R C$ referred patients for research studies and collated information on phenotypes. $\mathrm{IB}, \mathrm{HL}, \mathrm{HJ}$ and $\mathrm{RC}$ prepared DNA samples and collated information on phenotypes. KS, IB, CVL, SC, HL and CAJ screened MKS genes. KS, IB and CAJ contributed equally to the preparation of the manuscript. All authors read and approved the final manuscript.

\section{Acknowledgments}

We are grateful to the many families and their clinicians that have contributed to this study. The authors would like to acknowledge funding from the European Community's Seventh Framework Programme FP7/2009 under grant agreement no: 241955, SYSCILIA (http://syscilia.org/) and the Newlife Foundation for Disabled Children.

\section{Author details \\ ${ }^{1}$ Section of Ophthalmology and Neurosciences, Leeds Institute of Molecular Medicine, St. James's University Hospital, Leeds, UK. ${ }^{2}$ Yorkshire Regional Genetics Service, St. James's University Hospital, Leeds Teaching Hospitals NHS Trust, Leeds, UK. ${ }^{3}$ GeneTech Lab, 46/1 Shadman Colony, Jail Road, Lahore, Pakistan. ${ }^{4}$ Department of Obstetrics \& Gynaecology, King Edward Medical College, Lahore, Pakistan. ${ }^{5}$ Department of Clinical Genetics, Chapel Allerton Hospital, Leeds Teaching Hospitals NHS Trust, Leeds, UK. ${ }^{6}$ Peninsula Clinical Genetics Service, Royal Devon and Exeter NHS Foundation Trust, Exeter, UK.}

\section{Received: 28 March 2012 Accepted: 21 June 2012}

Published: 1 October 2012

\section{References}

1. Huang L, Szymanska K, Jensen Victor $L$, Janecke Andreas R, Innes AM, Davis Erica E, Frosk P, Li C, Willer Jason R, Chodirker Bernard N, Greenberg CR, McLeod DR, Bernier FP, Chudley AE, Müller T, Shboul M, Logan CV, Loucks CM, Beaulieu CL, Bowie RV, Bell SM, Adkins J, Zuniga Fl, Ross KD, Wang J, Ban MR, Becker C, Nürnberg P, Douglas S, Craft CM et al: TMEM237 is mutated in individuals with a Joubert Syndrome related disorder and expands the role of the TMEM family at the ciliary transition zone. Am J Hum Genet 2011, 89:713-730.

2. Williams CL, Li C, Kida K, Inglis PN, Mohan S, Semenec L, Bialas NJ, Stupay RM, Chen N, Blacque OE, Yoder BK, Leroux MR: MKS and NPHP modules cooperate to establish basal body/transition zone membrane associations and ciliary gate function during ciliogenesis. J Cell Biol 2011, 192:1023-1041.

3. Sang L, Miller Julie J, Corbit Kevin C, Giles Rachel H, Brauer Matthew J, Otto Edgar A, Baye Lisa M, Wen X, Scales Suzie J, Kwong M, Huntzicker EG,
Sfakianos MK, Sandoval W, Bazan JF, Kulkarni P, Garcia-Gonzalo FR, Seol AD, O'Toole JF, Held S, Reutter HM, Lane WS, Rafiq MA, Noor A, Ansar M, Devi AR, Sheffield VC, Slusarski DC, Vincent JB, Doherty DA, Hildebrandt F et al: Mapping the NPHP-JBTS-MKS protein network reveals ciliopathy disease genes and pathways. Cell 2011, 145:513-528.

4. Li A, Saito M, Chuang J-Z, Tseng Y-Y, Dedesma C, Tomizawa K, Kaitsuka T, Sung C-H: Ciliary transition zone activation of phosphorylated Tctex-1 controls ciliary resorption, S-phase entry and fate of neural progenitors. Nat Cell Biol 2011, 13:402-411.

5. Garcia-Gonzalo FR, Corbit KC, Sirerol-Piquer MS, Ramaswami G, Otto EA, Noriega TR, Seol AD, Robinson JF, Bennett CL, Josifova DJ, García-Verdugo JM, Katsanis N, Hildebrandt F, Reiter JF: A transition zone complex regulates mammalian ciliogenesis and ciliary membrane composition. Nat Genet 2011, 43:776-784.

6. Smith UM, Consugar M, Tee $L$, McKee BM, Maina EN, Whelan S, Morgan NV, Goranson E, Gissen P, Lilliquist S, Aligianis IA, Ward CJ, Pasha S, Punyashthiti R, Malik Sharif S, Batman PA, Bennett CP, Woods CG, McKeown C, Bucourt M, Miller CA, Cox P, Algazali L, Trembath RC, Torres VE, Attie-Bitach T, Kelly DA, Maher ER, 2nd Gattone VH, Harris PC et al: The transmembrane protein meckelin (MKS3) is mutated in Meckel-Gruber syndrome and the wpk rat. Nat Genet 2006, 38:191-196.

7. Doherty D, Parisi MA, Finn LS, Gunay-Aygun M, Al-Mateen M, Bates D, Clericuzio C, Demir H, Dorschner M, van Essen AJ, Gahl WA, Gentile M, Gorden NT, Hikida A, Knutzen D, Ozyurek H, Phelps I, Rosenthal P, Verloes A, Weigand H, Chance PF, Dobyns WB, Glass IA: Mutations in 3 genes (MKS3, CC2D2A and RPGRIP1L) cause COACH syndrome (Joubert syndrome with congenital hepatic fibrosis). J Med Genet 2010, 47:8-21.

8. Iannicelli M, Brancati F, Mougou-Zerelli S, Mazzotta A, Thomas S, Elkhartoufi N, Travaglini L, Gomes C, Ardissino GL, Bertini E, Boltshauser E, Castorina P, D'Arrigo $S$, Fischetto $R$, Leroy $B$, Loget $P$, Bonnière $M$, Starck $L$, Tantau J, Gentilin B, Majore S, Swistun D, Flori E, Lalatta F, Pantaleoni C, Penzien J, Grammatico P, International JSRD, Study Group, Dallapiccola B, Gleeson JG et al: Novel TMEM67 mutations and genotype-phenotype correlates in Meckelin-related ciliopathies. Hum Mutat 2010, 31:E1319-E1331.

9. Khaddour R, Smith U, Baala L, Martinovic J, Clavering D, Shaffiq R, Ozilou C, Cullinane A, Kyttälä M, Shalev S, Audollent S, d'Humières C, Kadhom N, Esculpavit C, Viot G, Boone C, Oien C, Encha-Razavi F, Batman PA, Bennett CP, Woods CG, Roume J, Lyonnet S, Génin E, Le Merrer M, Munnich A, Gubler MC, Cox P, Macdonald F, Vekemans M et al: Spectrum of MKS1 and MKS3 mutations in Meckel syndrome: a genotype-phenotype correlation. Hum Mutat 2007, 28:523-524.

10. Consugar MB, Kubly VJ, Lager DJ, Hommerding CJ, Wong WC, Bakker E, Gattone VH, Torres VE, Breuning MH, Harris PC: Molecular diagnostics of Meckel-Gruber syndrome highlights phenotypic differences between MKS1 and MKS3. Hum Genet 121:591-599.

11. Brancati F, Travaglini L, Zablocka D, Boltshauser E, Accorsi P, Montagna G, Silhavy JL, Barrano G, Bertini E, Emma F, Rigoli L, International JSRD Study Group, Dallapiccola B, Gleeson JG, Valente EM: RPGRIP1L mutations are mainly associated with the cerebello-renal phenotype of Joubert syndrome-related disorders. Clin Genet 2008, 74:164-170.

12. Tallila J, Jakkula E, Peltonen L, Salonen R, Kestila M Identification of CC2D2A as a Meckel syndrome gene adds an important piece to the ciliopathy puzzle. Am J Hum Genet 2008, 82:1361-1367.

13. Mougou-Zerelli S, Thomas S, Szenker E, Audollent S, Elkhartoufi N, Babarit C, Romano S, Salomon R, Amiel J, Esculpavit C, Gonzales M, Escudier E, Leheup B, Loget P, Odent S, Roume J, Gérard M, Delezoide AL, Khung S, Patrier S, Cordier MP, Bouvier R, Martinovic J, Gubler MC, Boddaert N, Munnich A, Encha-Razavi F, Valente EM, Saad A, Saunier S et al: CC2D2A mutations in Meckel and Joubert syndromes indicate a genotype-phenotype correlation. Hum Mutat 2009, 30:1574-1582.

14. Chen J, Smaoui N, Hammer MBH, Jiao X, Riazuddin SA, Harper S, Katsanis N, Riazuddin S, Chaabouni H, Berson EL, Hejtmancik JF: Molecular analysis of Bardet-Biedl syndrome families: report of 21 novel mutations in 10 genes. Invest Ophthalmol Vis Sci 2011, 52:5317-5324.

doi:10.1186/2046-2530-1-18

Cite this article as: Szymanska et al:: Founder mutations and genotypephenotype correlations in Meckel-Gruber syndrome and associated ciliopathies. Cilia 2012 1:18. 